\title{
Perceptions of hot climate in medieval cosmography and travel literature
}

\section{Article}

Published Version

Metzler, I. (1997) Perceptions of hot climate in medieval cosmography and travel literature. Reading Medieval Studies, XXIII. pp. 69-105. ISSN 0950-3129 Available at https://centaur.reading.ac.uk/84748/

It is advisable to refer to the publisher's version if you intend to cite from the work. See Guidance on citing.

All outputs in CentAUR are protected by Intellectual Property Rights law, including copyright law. Copyright and IPR is retained by the creators or other copyright holders. Terms and conditions for use of this material are defined in the End User Agreement.

\section{www.reading.ac.uk/centaur}

\section{CentAUR}

Central Archive at the University of Reading

Reading's research outputs online 


\section{Perceptions of Hot Climate in Medieval Cosmography and Travel Literature}

\section{Irina Metzler}

University of Reading

This article is an attempt to examine how climate, especially hot weather in exotic locations, was viewed by European travellers and writers in the middle ages. ${ }^{1}$ Of course, hot weather, especially hot summers, were not unknown in the Europe of the medieval period. One has only to think of 'the little optimum of the middle ages [which] caused Europe to experience various gusts of warmth, and even sometimes great heat'. ${ }^{2}$ The interests of this article, however, concern the response to the differences in temperature perceived by medieval travellers when they journeyed to foreign climes, to the south and to the east of the known world of medieval Europe, and how the climate was seen to affect the inhabitants in those places, both in the writings of actual observers (travellers) and in the texts of those evaluating and commenting on natural phenomena (scholastics and other non-travelling authors). Most of the sources I have used can be found in the accounts of Marco Polo, travelling to China ${ }^{3}$ and East Asia between 1271 and 1292, Odoric of Pordenone ${ }^{4}$ who visited almost the same regions a little later between 1318 and 1330, and the highly popular travelogue by the author known as Sir John Mandeville, who compiled his fictional account from the corpus of travel literature available to him around 1356, drawing heavily on Odoric amongst others; texts by other authors I have used are provided with references and details in the notes as they occur. Medieval Europeans did of course have some knowledge of East Asia and of China prior to Marco Polo's travels there, ${ }^{5}$ and several of these now not so well-known travellers and authors directly or indirectly influenced the picture of the world the better-known travellers had, especially the subsumption of Greek geographical and cosmographical theories via the translation of Arabic authorities into western European science. Theories of natural philosophy, as expounded by Scholasticism, found their way in to the mental image of the world that the actual observers/travellers had, thereby forming the paradigm 
according to which such observers tried to objectify and explain what they saw. Preconceived ideas of what it was like in other regions therefore shaped the (interpretative) descriptions of those regions by the observer, or, to put it another way, a certain type of description is demanded rhetorically for the author of a travel text to be believable. Since climate is one of the many natural factors seen to affect human beings according to scholastic natural philosophy, therefore strange, unusual or foreign climate is of importance, and as one specific type of climate heat is of paramount importance for understanding how and why medieval travel accounts express the sentiments they do when confronted with deviations from the European norm.

\section{Theory}

The concept of 'nature' in the middle ages can be approached in a variety of ways. Philosophically, the world as perceived in the middle ages can be described according to the tripartite conceptual elements of nature, art and chance. This is essentially an Aristotelian concept, taken up by Scholasticism. ${ }^{6}$ Accordingly, nature is that which is; it is the cause of motion and of rest in those things which exist per se and not through either chance or art. Art is anything that is done, acted or made by human activity, eg. throwing a stone upwards into the air, against gravity, is art. Chance is that which obeys its own laws, if it has any laws; anything not part of either nature or art is governed by chance. As nature, art and chance interact, so climate (nature) and human culture (art) can interact in the medieval scholastic view. More generally, one could approach 'nature' from the point of view that nature is a force interacting with and imposing on human culture. So some historians have investigated how this view was taken in the past, ${ }^{7}$ and how historic societies developed their concepts of 'nature'. In recent times the study of concepts as a study of mentalities, as was practised, for example, by the Annales school or the exponents of 'psychohistory' in the 1970s, has come increasingly to be criticised. The problem of the validity or the usefulness of a notion of mentalities was raised; some such notion is to a degree indispensable when attempting to understand the differences between the context of specific ideas, beliefs, or a whole network of concepts, ${ }^{8}$ but the question of how appropriate, valid or even applicable the notion of mentality is cannot be ignored.

Historians have examined, and are still examining, how environmental factors such as climate (or disease, for example) have 
affected human societies. 'Although some past expressions of environmental determinism now appear to us crudely simplistic and woefully ill informed, there has been a recurrent fascination among historians (and others outside the historical profession) with the idea of geographical, climatic or biological determinism and the belief that human societies are shaped (and differentiated from one another) by their physical location and environmental circumstances'. ${ }^{9}$ What I am attempting to achieve in the present article is a study of historic environmentalism (looking at what medieval people had to say about their environment) as opposed to the study of environmentalist history (looking at how we think the environment has shaped a past society).

Studies of historic environmentalism are defended by those who are otherwise critical of the study of mentalities as an all-embracing attitude held by all people of a particular culture. So for example D. Arnold has pointed out that 'it is, however, worth reflecting how diversely different ages and societies have understood this environmentalist idea'. ${ }^{10}$ One strand of the environmentalist paradigm is formed by the close connection between climate, health and medicine, an idea running from Greek antiquity, via the middle ages, through to the eighteenth century. This notion 'has arguably been one of the most powerful and pervasive idioms in which the environmentalist idea has historically been expressed'. ${ }^{11}$ The other strand of the paradigm encapsulates the notion of using the environment to establish 'otherness'. Here ethnography, in the medieval period quite closely linked with medicine and climate, is used as a way of explaining cultural differences. The norm, in this case the known world of the observer/writer from medieval Christian Europe (or from medieval Islamic culture) is juxtaposed with the unknown world of the 'exotic' people of Asia and Africa, and environmentalism is one method of explaining such perceived differences. In this way '...it is demonstrable that a sense of normality, continuity and affinity is invariably sustained by conjuring contraries and indices of difference'. ${ }^{12}$

\section{Medieval geographical notions}

Medieval geography and climatology ${ }^{13}$ followed the traditions established by antiquity, by the texts of such authorities as Aristotle, ${ }^{14}$ Plato $^{15}$ and Pliny. ${ }^{16}$ The Commentary on the Dream of Scipio by Macrobius (395-436) was probably the most influential cosmological text. Medieval writers such as Bede (in his De natura 
rerum) follow Macrobius and the zonal theory he proposed. The Geography of Ptolemy (Claudius Ptolomaeus, active around $150 \mathrm{AD}$ ), the most famous ancient geographer, was unknown in medieval Europe however until its rediscovery and translation c.1410. ${ }^{17}$ The combination of what was known in the medieval period of the corpus of antique cosmographical literature with Christian philosophy and patristic doctrine provides the classic scholastic picture of the world consisting of three continents, Asia, Europe and Africa, entirely surrounded by water. Representations of the world from the period c.1200-1500 are often in the form of the familiar tripartite maps, known as T-O maps, though sometimes called Noachid maps. ${ }^{18}$ It was believed that after the Flood the world was divided up so that each son of Noah received a part: Shem the first born received Europe, Japheth Asia and Ham got Africa. According to the patristic author Jerome ${ }^{19}$ Ham received Africa because his name is derived from 'hot' (calidus), and also the ninth-century exegete Angelomus ${ }^{20}$ connects Ham and his progeny specifically with Africa because of the climate. ${ }^{21}$

Additionally, the earth was divided into five, sometimes seven, climatic zones, termed Macrobian zones after the author who was in the middle ages the best-known zonal theorist. The hottest was to be found around the equator, the coldest on the poles, with the temperate zones between them. ${ }^{22}$ How widely accepted zonal theory was can be seen in that Macrobian zones also feature in a 'popular' (as opposed to 'scientific') work such as in the Travels by Mandeville, who says: For the superficialtee [ie. height] of the erthe is departed [ie. divided] in vii. parties for the vii. planetes, and tho parties ben clept clymates'. ${ }^{23}$ There was a widely prevalent geographical hypothesis, though not a universally supported one, that the central zone was too hot to be inhabited. This tropical torrid zone could not be traversed, an idea found first in a work attributed to Bede. ${ }^{24}$ The inhabitants of the northern temperate zone could therefore not reach those people living to the south of the equator, nor could they reach us, a geographical separation which poses interesting religious problems. ${ }^{25}$ So for example the anonymous author of the De imagine mundi (c.1100), as well as Gervase of Tilbury and William of Conches (c.1080-1154) were proponents of the uninhabitable equator theory. ${ }^{26}$ The uninhabitability view is echoed in more or less diluted form in popular literature, right down to the fourteenth century, so an armchair traveller such as Mandeville can say that while the lands in the north are so cold no one can live there, 'in the contrarye toward the south it 
is so hoot that no man ne may dwelle there, because that the sonne whan he is vpon the south casteth his bemes alle steght vpon that patye'. ${ }^{27}$ Meanwhile, though, the work of Raymond of Marseilles and Peter Alphonsi, who were both influenced by Arab thought, and Plato of Tivoli's translation of Al-Battani's texts expressed the inhabitable equator theory. ${ }^{28}$ In a work of around 1260 of Albertus Magnus the theory of seven climatic zones is proposed, with a central, hot zone that is inhabitable, therefore the temperate zones in the antipodes must be inhabited; the existence and the peopling of the antipodes are clearly enunciated in the text. The only reason that people from the south haven't come to us is because of the sheer vastness of the seas separating us. ${ }^{29}$ Roger Bacon, writing around 1266, discusses general points of geography, such as the spherical shape of the earth, the theory of longitudes and latitudes, and posits that the antipodes exist and furthermore that they are inhabited. ${ }^{30}$ Pietro d'Abano (c.12501316), the famous heretic and physician at the university of Padua, visited Marco Polo to hear from him at first hand some practical supporting evidence for Pietro's theory that the equatorial zone is inhabited. In his Conciliator (1303) Pietro records Marco Polo's observations of the tropical regions and can utilize them to substantiate his belief that the equatorial zone can be inhabited and traversed. ${ }^{31}$

\section{Far off places, monstrous races}

The antipodes could be peopled with strange and wonderful inhabitants, the monstrous races ${ }^{32}$ whose imaginative origins can be traced back to the authors of Latin antiquity, such as Pliny, ${ }^{33}$ via the highly influential Etymologiarum libri of Isidore, but also the farther corners of the known world, namely the extremities of Africa or the farthest East, could house the marvellous. The more of the world became known to the post-Classical European image of it, the farther the Plinian races receded, mentally and geographically. By the time William of Rubruck ${ }^{34}$ travelled across central Asia to the court of the Mongols in the 1250s he could be sceptical enough about the 'marvels of the east' to believe what he heard from the locals and discard received (European) wisdom: he asked some priests from China about 'the monsters or human freaks who are described by Isidore and Solinus, but was told that such things had never been sighted, which makes us very much doubt whether [the story] is true' ${ }^{35}$ Almost a century later another European in Asia, John of Marignolli in the early 
fourteenth century, is equally sceptical of monstrous races, using a perfectly logical explanation to debunk some of the mythical aspects:

I have travelled in all the chief countries of the earth ... and yet I never could ascertain as a fact that such races of men really do exist, whilst the persons whom I met used to question me in turn where such were to be found. The truth is that no such people $d o$ exist as nations, though there may be an individual monster here and there. Nor is there any people at all such as has been invented, who have but one foot which they use to shade themselves withal. But as all the Indians commonly go naked, they are in the habit of carrying a thing like a little tentroof on a cane handle, which they open out at will as a protection against sun or rain. this they call a chatyr [from Persian chatr = umbrella]; I brought one to Florence with me. And this it is which the poets have converted into a foot. ${ }^{36}$

It is interesting to note that the umbrella is used as a protection against both the wet and the heat. Nevertheless, physically travelling to exotic locations did not always automatically eradicate a frame of mind delighting in the exotic. Other travellers still cling to the monstrous races idea: the Libro del Conoscimiento ${ }^{37}$ written c. 1350 by a Spanish Franciscan friar includes the fabulous beings and monstrous anthropoid hybrids of ancient tradition, even though the friar had (apparently) actually explored extensively in Africa and the East, and was not just a Mandevillian armchair traveller. It is no coincidence that the monstrous races, if they are not located at the very edges of the world, are often situated geographically in the tropics, the equatorial or torrid zone of medieval cosmology. It has been pointed out that the tropics had a special significance for the (northern) European. 'The tropics existed only in mental juxtaposition to something else - the perceived normality of the temperate lands. Tropicality was the experience of northern whites moving into an alien world - alien in climate, vegetation, people and disease' ${ }^{38}$

Of the monstrous races, sometimes called Plinian races, the Bragmanni or Gymnosophisti and the Ethiopians, representing respectively a mythical India and an equally mythical Africa, ${ }^{39}$ are the peoples most approximating the real India and Africa the medieval European would have heard of or even travelled to. Bragmanni, obviously a corrupted form of 'brahman', and Gymnosophisti were 
often confused; both people were famous in medieval literature as the naked wise men, often encountered in the Alexander-romances, ${ }^{40}$ who either spend their days in caves to avoid the heat in the case of the Bragmanni, or, in the case of the Gymnosophisti, ${ }^{41}$ stand in fire and are able to stare at the sun. The Ethiopians, in the kind of etymology popularised by Isidore, get their name from aith (Greek $\alpha i \theta \omega$ : burn, blaze) + ops (Greek: face); the colouring of their skin is seen as a result of the climate.

\section{Impact of humoral theory on ethnography}

The predominant medieval scientific view held that the humoral theory derived from ancient authors could also be affected by the climate. Ultimately, this view goes back to a treatise entitled Airs, Waters, Places ascribed to Hippocrates, ${ }^{42}$ reiterated and expanded by Herodotus, ${ }^{43}$ Plato, $^{44}$ Aristotle ${ }^{45}$ and taken up by the ancient Latin authors, ${ }^{46}$ thereby finding its way into the corpus of medieval literature. As an example, in the ninth century John Scotus Erigena explains the diversity of the human race as resulting from the Fall and the accidents of climate: since the Fall 'there has also been a variety of departures in qualities, size, and in other ways from the original single form. Changes in individual characteristics [morphology] do not have their origin in nature [ie. in the primordial prelapsarian form], but arise from the sin and the Fall and from spatial and temporal differences owing to the land, water, air, food, and similar circumstances. It is known to all that differences in customs and in ways of thinking came into being after the sin and the Fall'.47

Places and their properties are closely linked together; when medieval writers try to explain national or cultural differences they rely heavily on what we would term environmentalism. Here an example from Isidore: 'In keeping with the differences in climate, the looks of men, their colour, and their stature vary, and different dispositions appear. Consequently the Romans are stately, Greeks shifting, Africans sneaky, Gauls warlike by nature and plunge into things, all because the climates they live in differ' ${ }^{48}$ Notions of the mixture and the proportion of things (humours, climates, elements etc.) draw attention to the influence of a given locality in creating various combinations of elements and thus creating difference. These sorts of theories are found in the de natura locorum or de proprietatibus rerum types of encyclopedic treatises, ${ }^{49}$ throughout the middle ages, especially under the influence of scholasticism. Such texts contain 
important sections of works which normally include some geography, and passages on the four elements, humours, mixtures and qualities. Gervase of Tilbury, an English clerk writing for the Welf emperor Otto IV, expresses these views on climate and ethnic character, drawing heavily on the established stereotypes: 'According to the difference of the air and climate, the Romans were grave, the Greeks fickle [leves], the Africans crafty [versipelles], the Gauls naturally fierce, the English ingenis potentiores and the Germans robust'. ${ }^{50}$ Note the rather more positive description of the emperor's own (German) ethnic group! A writer from a different geographical location and subsequently with a different viewpoint of ethnic superiority is Jacques de Vitry, who contrasts the sober and tight-lipped people from south of the Alps, ie. the merchants of the Italian city-states, with those of more excitable and impulsive tempers from north of the Alps, ${ }^{51}$ i.e. the French. Interestingly enough, the predominant geoclimatological scheme of southerly and hot predisposing to excitability, and northerly and cold being equated with rational is not being adhered to in this case. The connection perceived between the climate and the racial or cultural characteristics of a people is expressed clearly in the following example from Albertus Magnus' De natura locorum:

The place where men grow strongest seems to be most suitable for habitation. For where men are more generally handsome and brave and noble of stature, there man thrives more readily ... For this reason the fourth clime and the fifth one which is neighbouring it are laudable, and are midway between these excellences, having the laudable middle properties of both regions; this can easily be understood by anyone who knows that the mean is determined by the extremes. Moreover, the life of those there is long ... and their customs good ... But the customs of the northern people are wolfish ... the people of the south are light-hearted. The middle people, however, between these easily cultivate justice ... embrace peace, and love the society of men. ${ }^{52}$

This passage from one of the most influential scholastics manages to combine geography, climate, aesthetics, morals and the concept of the 'golden mean' and may stand for a summary of the predominant 
medieval views on these matters, from the learned schoolmen to writers of popular literature to travellers' reports.

In medieval Arabic literature, too, there is a similar current of thought, ${ }^{53}$ due to the common origin of both Arabic and Western medieval natural philosophy in ancient Greek texts. Black people's appearance, the colour of their skin and their, in Arab eyes, ugly features are due to the climate. The climate is also to blame for the northerners being too white, phlegmatic and having bodies that are far too large - all because of the excessive cold. Furthermore, Arabic ethnology and geography pictured much of China, India and all of the Arabian peninsula, lands regarded as being in the hot climatic zone by both Christian and Arabic writers, as temperate, because these areas are surrounded by seas providing a mitigating effect on the excessive heat through the humidity generated by water. 'It was social judgment which ultimately determined the degree to which credence would be given to geographical determinism, and this determinism was applied mercilessly only in the construction of sheer barbarism...., ${ }^{54}$ so that the rationale of expanses of water cooling otherwise hot lands, as happened to India or Arabia, was not applied to the Horn of Africa or the islands of the Indian ocean in the same way because these places were seen a priori to be barbaric and exotic. Both the medieval Arabic and Christian learned discourse is informed by a 'natural-scientific ecological determinism mediated through the notions of humoral medicine'. 55

Other kinds of texts besides the geographical or cosmographical treatises are also reiterating notions of climate and cultural characteristics. The Chronicles of Benoît of Sainte-Maure, written around 1150 , describe the extreme south as 'regions where the days are hot and burning... [there are] people of different kinds who have no law, religion, or reason, justice or discretion; not knowing the difference between right and wrong, they are more felonious than dogs' ${ }^{56}$ The inhabitants are black, chinless, large and horned, they are hairy right down to the ground, furthermore they have hanging ears, long noses and large feet. This is in fact meant to be a description of the Ethiopians, but Benoît has managed to throw in the attributes of several of the monstrous races (eg. horned Satyrs, long-eared Panoti and Sciopods with their one over-dimensional foot) for good measure. ${ }^{57}$ Authors of husbandry and 'life-style' manuals for the nobility, such as Pietro de Crescenzi, ${ }^{58}$ also picked up and reiterated these ideas of place and climate. On heat and humours and their impact 
on the body he has to say that air that is too hot is not good, causing a variety of humoral imbalances, that is why it is not good for healthy bodies but can aid those with certain ailments, like 'paralytics and those with too much humour in the nerves and veins'. ${ }^{59}$ Expanding these theories to climate in general, Pietro de Crescenzi remarks that hot places make the hair multiply and grow curly, and brings old age about sooner, like for the Moors of Mauretania for whom 'old age arrives at thirty years, and their hearts are timorous'. ${ }^{60}$ As an exponent of popular travel literature, Mandeville also repeats climate and character theories, this time adding an astrological element. Having at an earlier point mentioned that the Indian climate is ruled by Saturn, Mandeville now links this astrological statement with a social one: the people of India are not great travellers because they are in the first climate, which is the climate of Saturn, and Saturn is slow , moving very little, therefore the people of that climate are like their governing planet. ${ }^{61}$

Other aspects of climate and character/culture theories are also explored by medieval writers. A very revealing connection is made by Gerald of Wales, who in a discussion on the enemies of the Church makes interesting links between climatic conditions and manifestations of heresy. ${ }^{62}$ Speaking of the Moslems, whom Christian theological thinking regarded as heretical, he says that they abstain from wine because of the hot climate they live in, that they may not be endangered by the heat, and that in this they follow their master Mohammed; ${ }^{63}$ furthermore, the pressing heat of their region actually makes the Moslems lascivious (libidinosos) and therefore Mohammed allowed each man to have as many wives and concubines as he could support economically. ${ }^{64}$ In contrast to the Moslems, the Patari of Milan are heretics who not only inhabit the cold zones but they are also very avaricious, stating as if it were law that the tithe is to be withheld from priests and no payments are to be made to the Church. ${ }^{65}$ Heat creates lustful heretics who must be extra cautious about abstaining from alcohol, and cold creates penny-pinching revolutionaries who begrudge the priests their hard-earned cash, is how one could summarize Gerald's text.

The fullest expression of environmentalism, as in the impact of an environment regarded as natural on human life, actions or culture, is found in Albertus Magnus, who asserts that natives born and living in the hottest zone who migrated to one of the temperate zones would undergo a change in their skin colour from black to white. ${ }^{66}$ Such 
'hypermaterialism', in the sense of the complete submission of human beings to environmental factors, precludes the kind of objectifying, 'scientific' racism one encounters in the post-Enlightenment period, while nevertheless regrettably leaving open the door to subjective, individual racism, as can be found in the aesthetic judgments of many of the medieval travellers in their descriptions of the appearance of the 'other'.

\section{Asia imagined}

Travellers to India and south-east Asia frequently comment on the hot climate and the impact this has on peoples' lifestyle. Marco Polo said of the Coromandel coast in southern India that the climate is 'amazingly hot, which explains why they go naked. There is no rain except in the months of June, July and August. If it were not for the rain in these three months, which freshens the air, the heat would be so oppressive that no one could stand it. But thanks to this rain the heat is tempered. ${ }^{67}$ Furthermore, they have beds of a light construction to catch the breeze and combat the heat, ${ }^{68}$ and in Quilon (southern India) the people 'are all black-skinned and go stark naked, ${ }^{69}$ both males and females' except for colourful loincloths. ${ }^{70}$ There also 'the heat is so intense and the sun so powerful that it is scarcely tolerable. For I assure you that if you put an egg into one of the rivers you would not have long to wait before it boiled.. ${ }^{71}$ The heat has consequences for the animals living in India, not just for the humans, since according to Marco Polo 'the climate is so hot that horses cannot be bred and are not born, or, if they are, they are monstrosities, blemished and misshapen in their limbs and quite worthless'. ${ }^{72}$ The different size, shape and colour of the animals there, which are unlike anywhere else in the world, is also explained as a 'consequence of the extreme heat'. ${ }^{73}$ The topos of heat and lack of clothing ${ }^{74}$ is continued in travellers' descriptions from the fifteenth century. People in the kingdom of Mackeron (Madras), which is subject to the king of Moabar, are 'quite black, wearing little and being very immodest'75 as Arnold von Harff, a German knight, says of his journey in 1496-1499. Equally in Lack, also subject to Moabar, the people are 'quite black and go about usually quite naked, men and women, without even an animal's skin to cover their shame'. ${ }^{76}$ Athanasius [Afanassij] Nikitin, a Russian traveller in the Near East, Arabia, Persia and India from 1466-1472, describes India as the country where the people are all nude, their head is uncovered and the hair worn in a plait; all the 
women are pregnant, having children every year, and they have lots of children anyway; the men and women are all black; and wherever Athanasius goes he is followed around by many people all amazed at the white man. ${ }^{77}$ Even the attendants of the ruler are naked, barefoot and wild, the women too have their heads and even their breasts uncovered, and children are completely naked, ie. do not even wear a loincloth, until they are 7 years old. ${ }^{78}$

Farther towards the more remote regions of Asia, on the very fringes of the known world, people and customs were perceived as more different still. Odoric of Pordenone comments on the people of Lammori (Sumatra): 'And in that country the heat is so excessive that all the folk there, both men and women, go naked, not clothing themselves in wise. And they mocked much at me on this matter, saying that God made Adam naked, but I must needs go against His will and wear clothes'. ${ }^{79}$ The people of Lammori are perceived as a kind of noble savage, in their innocent, prelapsarian nudity. Odoric then continues by stating the inhabitants of Lammori practice polygamy, cannibalism, and a kind of primitive communism, keeping all their possessions in common. Mandeville picks up this passage, repeating it almost verbatim, ${ }^{80}$ but with interesting additions of his own, namely asserting that nothing, ie. no custom, is bad that is natural, and allowing the Lammorians to justify their position. ${ }^{81}$ Similarly, in the late fifteenth century, the people of Lack in India apparently mock the traveller Arnold von Harff for wearing clothes, arguing that Adam and Eve were naked, but Arnold retorts that 'if they spent a winter in our country [Germany] they would not copy Adam and Eve'. ${ }^{82}$ As in Odoric's story of Lammori, Arnold then relates how the people of Lack hold their wives and all their possessions in common. In medieval Arab literature the islands of the Indian ocean are also seen as exotic, not just because the inhabitants are generally (semi-)naked, with wide nostrils and kinky hair, but also because of the constant references to cannibalism made by the texts as an indicator of the natives' barbarity, ${ }^{83}$ from whence it is not a big leap of the imagination for the authors to arrive at the mirabilia-type of monstrous races and humanoid hybrids, including the legendary Gog and Magog, that were also current in medieval Christian discourse.

Another expression of the 'noble savage' topos can be found in the stories about the natives of the Nicobar islands. Odoric of Pordenone speaks of the people of the Nivoveran (Nicobar) islands, who are dogfaced, nude apart from a loincloth, but have stalwart warriors who 
enter battle with only a shield for cover ${ }^{84}$ and are ruled by a king who 'attends to justice and maintains it, and throughout his realm all men may fare safely'. ${ }^{85}$ In the fifteenth century, still, the people of the Nicobar islands are, according to Arnold von Harff, who in turn is following Mandeville, black, naked except for 'covering their shame with a raw skin' and have dogs' heads but are 'of good speech and understanding'. ${ }^{86}$ Both the people of Lammori and of Nicobar are situated on islands; islands have been regarded as special places (as in the 'isles of the blessed', for instance) ${ }^{87}$ with special people living there, in a tradition going back in Europe to the myths of the ancient Greeks, eg. the Utopia of Iambulos. ${ }^{88}$ The medieval utopia had taken over from antiquity the concept of a 'Wonderland' 89 situated in a far-off but still terrestrial place, located especially on an island. There happy people lived, with riches in abundance, but often these people are perceived as being of monstrous appearance. Such utopias are distinct from the concept of the Wonderland as positioned in an ideal city (which could be the civitas dei, or the heavenly Jerusalem) or state, nor do they fit in with the more down-to-earth medieval peasant's utopia of the land of Cockaigne.

Sometimes the heat was too much even for the people born in the hot zone, and the natives have to take a sort of evasive action to counter the tremendous temperature. An anonymous medieval writer said of the Brahmins: 'The fire of their sun is of such intense heat that as soon as it is diffused from heaven on to the earth all of them would be burnt did they not quickly plunge into the river'. ${ }^{90}$ This idea recurs in Mandeville, who says that 'in [Hormuz] and in Ethiope and in many other contrees the folk lyggen alle naked in ryueres and watres, men and wommen togedre, fro vndurne of the day tille it be passed the noon. And thei lyen alle in the water saf the visage for the gret hete that there is. And the wommen hauen no schame of the men but lyen alle togidre, syde to syde, tille the hete be passed. There may men see many foule figure assembled, and namely nygh the gode townes'. ${ }^{91} \mathrm{~A}$ different, and much more plausible, approach to overcoming the extreme heat of the day is described by Benjamin of Tudela, who was travelling the Holy Land, Egypt and the Near East, and relating stories of India, from 1169 to 1171. Speaking of Khulan (Quilon), in southern India on the Malabar coast, he says that 'all during the summer, no man can go out of his house because of the sun, for the heat in that country is intense, and from the third hour of the day onward, everybody remains in his house till the evening. Then they go 
forth and kindle lights in all the market places and all the streets, and then do their work and business at night-time. For they have to turn night into day in consequence of the great heat of the sun'. ${ }^{92}$ Less radical is the protection from the sun and its heat throught the use of an umbrella or parasol [chatr], as mentioned above by John of Marignolli in the early fourteenth century, ${ }^{93}$ but such a rather mundane and undramatic solution by the natives to the problem of too much heat, however, does not make for good (European) travellers' tales.

In India, Marco Polo says, '... men travel by night rather than by day, because it is cooler'. ${ }^{94}$ In the kingdom of Lack, subject to Moabar, no travel is possible before midday 'but only after midday and half through the night, on account of the great heat in that land.' The real exoticism ${ }^{95}$ of the imagined, or the geographical, 'India' becomes apparent when the reversal of the 'normal' lifestyle is mentioned by the European observer.

Not just native inhabitants, but also European travellers are seriously affected by unusual heat. During his 1403-1406 embassy to Tamerlane on behalf of king Henry III of Spain, the ambassador Clavijo, discussing the silk road, and caravan and trade routes in Central Asia, observes: 'These countries where silk is made are all so hot that any strangers who go there suffer much from sunstroke, which indeed at times may kill; they say that the stroke goes straight to the heart, causing first vomitings and then death. To the sufferers their shoulders will seem to burn, and they say too that those who escape with their lives ever afterwards are yellow in the face or gray, never regaining their natural complexion. ${ }^{196}$

\section{Africa imagined}

Western European travellers to Africa were even rarer than to India in the middle ages. It is therefore not surprising that further fanciful statements can be made about the north African desert region, and not just about India. An inscription attached to the portolan map of Giovanni di Carignano of around 1320 states about the Sahara of the Berbers there: 'Sometimes the heat is so great, when the sun is at its zenith, that they pass blood'. ${ }^{97}$ Mandeville is also rather imaginative about the climate in foreign strange parts: 'In that see of libye is no fissch, for thei mowe not lyue ne dure for the gret hete of the sonne, because that the water is euermore boyllynge for the gret hete'.$^{98}$ The knowledge about the lands farther south is even more nebulous: 'And 
beyonde that partie [of Ethiopia] toward the south to passe by the See Ocean [ie. going by sea to the south] is a gret lond and a gret contrey, but men may not duelle there for the feruent brennynge of the sonne, so it is passynge hoot in that contrey. In Ethiope alle the ryueres and alle the watres ben trouble [tubid], and thei ben somdelle salte for the gret hete that is there'. ${ }^{99}$ It is interesting to note that Mandeville, who is presumed to have obtained a lot of his material from no farther away than the local library, has apparently not read any of the latest texts on the traversability of the equatorial zone; he still speaks of that central zone as of one where it is impossible for humans to exist.

The imagined or the real people living in Africa were as little known about as the land. In the thirteenth century the educated European view on the appearance of the people in Africa was informed by the natural science of humours and elements as propounded by, for example, Albertus Magnus. 'Owing to the great heat of their clime', he says, 'the earthly members which are inside them, as bones, become very white as is apparent in their teeth. Their flesh is suffused with blood as if they are glowing coals, as is apparent in their tongues and throats when their mouths are open. And they have prominent mouths, thick lips, reddened eyes, veins and eye lids on account of the heat'. ${ }^{100}$ When Marco Polo discussed the people of 'Zanzibar' (Zenj/Zanj ${ }^{101}$ an 'area of eastern Africa, probably corresponding to modern Somalia), he felt it necessary to comment not only on their lack of clothing, by now a familiar topic when Europeans wrote on hot countries, but also on their appearance: ${ }^{102}$ 'They are quite black and go entirely naked except that they cover their private parts. Their hair is so curly that it can scarcely be straightened out with the aid of water. They have big mouths and their noses are so flattened and their lips and eyes so big that they are horrible to look at. Anyone who saw them in another country would say that they were devils'. ${ }^{103}$ Though he is being very disparaging about the physical appearance of the Zenjians, Marco Polo does not explicitly say these people are devils, he brings in the cultural relativism, that anywhere else, implying anywhere where the norm is a different one, these people would be regarded as devils which in fact he realizes they are not. The disparagement of the image of the Africans is continued along aesthetic lines, rather than racist in the modern sense, in the description of the women that follows: 'The women of this island 104 are very ugly to look at. They have huge mouths, huge eyes, and huge 
noses, and their breasts are four times as big as those of other women. Altogether, their appearance is quite repulsive'.105

Medieval European views of other cultures and people were of course not free of value judgements, as we have seen, but the sentiments of an inherent intellectual and cultural inferiority ascribed to another group of people purely on account of their perceived racial characteristics appears to be absent from the more scholarly texts what the individual traveller thought is another matter, but then even the medieval traveller did not have access to the intellectual ammunition of an objectifying, 'rational' justification for superiority/inferiority as could be provided by later 'enlightened' texts. An early expression of this kind of tolerance, or attempt to broaden human sympathy for the different, can be found in patristic literature. Augustine, ${ }^{106}$ in a longer passage discussing the monstrous races, provides an argument roughly along the lines that because all of humanity descended from Adam, via the sons of Noah (with their separate continents), there can only be one human race to which even the monstrous races must belong - the common descent of all humanity allows for the acceptance of even the strangest people. M. Hodgen sums up this - medieval - Christian view: 'As long as all men were considered brethren in the family of God, as long as no efforts were made to classify some men among the beasts [author's italics], as long as no political or economic interest called for a theoretical imputation of debasement with respect to any group of dependent people, neither skin color nor the natural anxiety caused by conflict with enemies such as the Muslims or Tartars led to anything like what we now know as racial "tension".'107 Interestingly, some medieval Arabic scientific literature comes closer to expressing 'racist' ideas than the otherwise so intolerant patristic texts. For example, an author of medical texts, Costa ben Lucca of Baalbek ( $f$. 860), believed that spiritus, the power of intellect, was a 'subtle body' distinct from the soul, and therefore subject to environmental influence. 'The clearer and more subtle this spiritus is, the more readily it lends itself to mental processes, while the more perfect the human body, the more perfect the spiritus and the human mind. Hence the intellectual powers of children and women are inferior, and the same is true of races subjected to excessive heat or cold, like the Ethiopians or Slavs. '108 The tenth-century polymath Mas'udi (†c.956) subscribed to the Galenic thesis concerning the congenital mental deficiency of black Africans; also the Persian author Nasir al-Din Tusi who supported the 
same theory, irrespective of whether there was believed to be any medical evidence for Galen's opinions or not. ${ }^{109}$ Descriptions, both of their physical appearance and of their culture, of the Christian black Africans, generally called Ethiopians, though sometimes referred to as Nubians, exemplify the absence of the kind of 'scientific' racism our modern world has been plagued by since the nineteenth century. ${ }^{110}$ So for example Mandeville can talk about Christian Nubians in relativist, not racist, terms. 'And men of Nubye ben Cristen, but thei ben blake as the Mowres for gret hete of the sonne'. ${ }^{111}$ A continuation of this passage is provided in another modern edition based on an alternative manuscript source of Mandeville. ${ }^{112}$ 'But they are black in colour, and they consider that a great beauty, and the blacker they are the fairer they seem to each other. And they say that if they were to paint an angel and a devil, they would paint the angel black and the devil white. And if they do not seem black enough when they are born, they use certain medicines to make them black. That country is marvellously hot, which makes its folk so black'. ${ }^{113}$ Literature other than narratives of (real or imagined) travels also finds it worth mentioning that the black Nubians are Christians and not Islamic Moors, whom they are perceived to resemble, in contrast to what the author would expect from their appearance, assuming that Christians are white and people of other religions, especially Islam, are black. In a poem of 1389 Philippe de Mezières tells of a Venetian called Bragadino who went to Ethiopia; Bragadino says of the king of the Nubians that he is 'black as a Moor'114 but a Christian. The Arabic writers too regarded the Ethiopians as the most exalted of black Africans, not, of course, because of their Christianity, but because they were perceived as 'civilized' by virtue of having a territorial state; so civilized in fact that Arabic rulers chose their eunuchs from among the Ethiopians. ${ }^{115}$

Amongst all the mythical narratives and imagined journeys there are Europeans who actually travelled to Ethiopia. One such person was Pietro Rombulo from Messina, who went to Ethiopia as a young man in 1407, staying there for 37 years, subsequently travelling to India and China on a mission for the Byzantine emperor and finally returning to Naples in 1450 . Rombulo appears to have been the first medieval European who travelled to exotic places not primarily for commercial or religious (missionary) purposes, but purely out of curiosity. ${ }^{116}$ Back in Naples Rombulo encountered the Dominican Pietro Ranzano, and a rather amusing example of European stereotyping. Hearing he was to speak with someone from Ethiopia, 
Ranzano expected to meet with a dark-skinned Ethiopian speaking some barbaric language. To Ranzano's surprise, the perfectly normal Italian-looking Pietro Rombulo turned up. ${ }^{117}$ Francesco Suriano, a European traveller to Ethiopia writing his Iter in 1482, left us this description of the inhabitants: 'No one wears woollen cloth because they have none, but instead they wear linen. All, both men and women, go naked from the waist upwards and barefoot; they are always full of lice. They are a weak people with little energy or application, but proud. They are zealots for the faith, and of a fervent spirit above all other Christians'. ${ }^{118}$ Whatever negative views the author has of the Ethiopians, their fervent Christianity is a most redeeming feature in medieval European eyes. Furthermore, the Ethiopians (or Nubians), though seen as exotic and representative of the 'other', were regarded as potential allies of Christian Europe against Moslem North Africa and the Near East, and therefore not quite as extraordinary as their climate, location or appearance might make them.

\section{Familiarity and realistic descriptions}

Some regions of North Africa and the Near East were of course relatively well known to the Christian European, these being the places associated with biblical geography. The descriptions of people, topography, and natural phenomena, dealing with more familiar regions, become far more realistic for such localities. Not many of the authors of pilgrimage guidebooks to Jerusalem during the crusading period have anything to say about the climate. They are obviously far more concerned with writing about the real topic of their guides, which is of course about the holy sites to be visited there, though sometimes comments of general concern to the traveller like the condition of the road between holy places, or the quality of the water, are made. Even two Icelandic pilgrims who left written accounts do not comment about the (radically different) climate of the Near East. An exception appears to be Saewulf, probably of Anglo-Saxon or German origins, who travelled to the Holy Land 1101-1103. He said of the perils facing pilgrims that 'many are killed by the Saracens and many of heat and thirst - many through lack of drink and many from drinking too much'. ${ }^{119}$ Heat is here purely a force that affects the individual, and there is no extrapolation from individual experience to generalizing statements about climate and the human condition as a whole; after all, the topic of the pilgrimage guides is in the first 
instance the holy land and its sites, not the subject of ethnography. But then even Mandeville, who is generally a lot more fanciful, manages to obtain an accurate if rather bland description of the Lybian desert from one of his sources: 'And toward the west [of Egypt] is the [contre] of Lybye, that is a fulle drye lond and littyle of fruyt, for it is ouermoche plentee of hete'. ${ }^{120}$

The German knight Arnold von Harff travelled to the Near East and the Egypt, returning to Germany by way of Spain and France, during 1496 to 1499. He says that it hardly ever rains in Egypt or Arabia; rain, thunder or hail are unknown to the inhabitants and one hardly ever sees clouds in the sky 'for there is always great heat'. ${ }^{121}$ The same author also notes in connection with a crossing of the desert between Cairo and the monastery of St Catherine that many people died on the caravan journey 'through suffocation by the great heat'122 and lack of water. The harshness of desert conditions is portrayed accurately and without too much Eurochristian sentimentality, as when Arnold mentions the necessity for the caravan leader to press on in search of water, irrespective of any weak or ill members; many people and camels were seen 'lying exposed in the sand, all suffocated by the heat of the sun' and the 'wild Arabs' (ie. Bedouins or other nomads) accompanying Arnold's caravan rushed towards the bodies of the dead to see if there was any money on them, subsequently leaving them 'without pity, unburied'. ${ }^{123}$ On another crossing of the same desert Arnold notes a well with very salty water in it, 'which was surprising, as they [his caravan] were far from the sea'. He was told that 'it seldom rains in those parts, and so seldom that the rain water itself, with the burning sun, falls into the hot sand, and the great heat of the sun makes the water salty, just as in winter time the great cold turns the water to ice. For this reason the water was salty. At night, by the light of the stars, we saw something glittering in the sand like gold. This was the rain-water congealed by the great heat of the sun'.124

A more factual approach to descriptions of foreign lands can also be found in relation to those more exotic locations normally eliciting the marvellous and the monstrous. As the geographical India became better known, in contrast to the mythical 'India' of the armchair travellers, missionaries such as the early fourteenth-century friar John of Montecorvino ${ }^{125}$ can provide a less imaginative picture of the region. After describing the cultural customs and religious practices of the people of India, he summarizes the subcontinent's inhabitants as follows: 
But India is a region of great extent, and it hath many realms and many languages. And the men thereof are civil and friendly enough, but of few words, and remind me somewhat of our peasants. They are not, strictly speaking, black, but of an olive colour, and exceedingly well formed both women and men. They go barefoot and naked, except that they wear a cloth around the loins, and boys and girls up to eight years of age wear nothing whatever, but go naked as they came from their mother's womb. They shave not the beard; many times a day they wash ... they eat grossly like pigs, to wit, with the whole hand or fist, and without a spoon. In fact, when at their food they do look more like pigs than men!126

Though making derogatory remarks based on his aesthetic principles, John de Montecorvino is here being not so much racist as classconscious: the inhabitants remind him of the peasants back home.

\section{Positive views of otherness}

That colour of skin is no impediment to 'correct' moral behaviour or religion is also observed of some Indian people by Benjamin of Tudela, who mentions a community of so-called black Jews at Khulam (modern Quilon) 'who knew Moses and the Prophets and to a small extent Talmud and Halachah'. ${ }^{127}$ And speaking of the people of northern India, possibly referring to Kashmir, Marco Polo gives a positive-sounding description of the inhabitants: 'The inhabitants are brown-skinned and thin; the women are very beautiful, with such beauty as goes with a brown skin... They enjoy a temperate climate, without extremes of heat or cold. ${ }^{128}$ Furthermore, there are plenty of towns and cities, a sign of civilization for Polo, the man from an Italian city-state, they have chaste and devout hermits, signifying a moral people, and they don't kill animals but have Moslems living with them who act as butchers for them. In other words, the Marco Polo account paints a picture of an almost 'normal' Christian, European people, where even the weather subscribes to the European norm. This link between climate and civilization can be found in another passage of Polo's text, too. Speaking of the provinces of Tun and Kain, in northeastern Persia, he again mentions that there are plenty of cities and towns, and that the people there enjoy great abundance of all good things 'for the climate is admirably tempered, 
neither too hot nor too cold... They are a good-looking race and the women in particular are of outstanding beauty. ${ }^{129}$

In direct contrast to the description of the Indian climate and how it affects the Brahmins suffering from the heat (see above) stands another view, given in the statement that the Brahmins live to 150 years of age 'because of the mild climate and the will of God' ${ }^{130}$ Note that yet again it is preconceived notions of the civilized or uncivilized state of a people that determines the description of the climatic condition. Dante's teacher Brunetto Latini $(† 1291)$ in his Li Livre dou Trésor attests that while much of the island of Taprobane (Sri Lanka) is desert owing to the heat, in contrast the region of India is noted for its temperate climate, ${ }^{131}$ a view that does not stem from Latini's more precise geographical knowledge, I believe, but from the imagining of his 'India' closer to the temperate zone and of his 'Taprobane' closer to the equatorial zone, so that here the value system attached to a hierarchy of the zonal system is the determining factor.

\section{Impact of climate on known regions}

Climate was not restricted to having an impact only on people in faroff foreign places. Nearer home, too, places with a hot climate were regarded as forcing their inhabitants to behave in a certain way. So Mandeville has the following to say on the heat in Cyprus: 'In Cipre is the manere of lordes and all othere men alle to eten on the erthe. For thei make dyches in the erthe alle aboute in the halle depe to the knee, and thei do paue hem, and whan thei wil ete thei gon therein and sytten there. And the skylle is for thei may ben the more fressch, for that lond is meche more hottere than it is here. ${ }^{132}$ Benjamin of Tudela, too, observes the impact of climate on the people of fairly well-known places. As part of his description of Baghdad he mentions the medical and hospital provisions made for the inhabitants by the Caliph. Among them is 'a building which is called Dar-al-Maristan, where they keep charge of the demented people who have become insane in the towns through the great heat in the summer, and they chain each of them in iron chains until their reason becomes restored to them in the winter-time. ${ }^{133}$ It is interesting to note that the people institutionalized there are provided with food and even sick-pay of sorts at the Caliph's expense, with examinations for return of sanity and subsequent discharge taking place on a monthly basis. ${ }^{134}$

The important trading post of Hormuz on the Persian Gulf is noted for its extreme heat by quite a few writers, whether they actually 
visited there or not. Marco Polo states that in Hormuz the climate is 'torrid, owing to the heat of the sun, and unhealthy'; ${ }^{135}$ the people are all black and 'in summer they do not stay in the cities, or they would all die of the heat; but they go out to their gardens... [parts of which are] covered with foliage to fend off the sun... [Coming from the direction of the desert dunes there is] a wind so overpoweringly hot that it would be deadly if it did not happen that, as soon as men are aware of its approach, they plunge neck-deep into the water and so escape from the heat'. ${ }^{136}$ The houses in Hormuz have been specially adapted to let the inhabitants cope with such temperatures and alleviate the heat, they are 'fitted with ventilators to catch the wind. The ventilators are set to face the quarter from which the wind blows and let it blow into the house. This they do because they cannot endure the overpowering heat'. ${ }^{137}$ Odoric of Pordenone has reached a similar verdict on the Hormuz climate, saying 'it is not a healthy place nor safe for life, and the heat is something incredible'. ${ }^{138}$ He continues: 'So extreme is the heat in this country, that the privates of men come out of their bodies and hang down even unto their mid-legs. And, therefore, the inhabitants of the same place, to preserve their own lives, do make a certain ointment, and anointing their privy members therewith, do tie them up in certain bags fastened to their bodies, for otherwise they must needs die'. ${ }^{139}$ Mandeville cites this passage verbatim, ${ }^{140}$ except that he calls the place Crues. And at Gurmys, near Hormuz on the Persian Gulf, the sun is hot and burns the people there, as are plenty of other familiar trading places in Persia, the Near East and on the Arabian coast according to a list of relative 'hotness' the Russian traveller Afanassij Nikitin draws up. ${ }^{141}$

\section{Environmentalism and climatological determinism}

Theories of the elements and the humours were combined with climatology to explain the human diversity of appearance and way of life. But also ' 'desert, forest, jungle and mountains' served as 'the physical stages' on which the western European consciousness could act out fantasies of wildness and savagery'. ${ }^{142}$ It just so happened that with increasing knowledge of the world, and exploration and discovery, the boundaries of the wild, wonderous or monstrous were pushed farther and farther to the periphery. By the time Hieronymous Bosch (c.1450-1516) had painted his triptych the Garden of Earthly Delights, ${ }^{143}$ showing people of mixed race, African and European together in a paradisiacal setting with no apparent racist overtones, the 
New World of Columbus was to become the focal point for notions of otherness that the undiscovered regions of the Old World had been.

That not a lot has changed in the past five or six hundred years since the end of the apparently 'dark' middle ages to our 'enlightened' scientific times can be seen in the following articles gleaned from a major daily newspaper within the last six months. In one, the novelist John Mortimer is singing the praises, rather ironically one would hope, of an impending climate change due to global warming, which would give England quasi-Mediterranean weather: 'God knows what the sunshine might do for us. We might come to be fonder of children than we are of animals. Perhaps we don't want to see donkeys dropping from church steeples, but it would be nice to see extended families in restaurants, with two-year-olds welcome to stagger between the tables. Someone said the English climate, apart from being a constant topic of conversation, produced a stable government'. ${ }^{144}$ More recently, in an article about establishing more cultural links between Britain and Australia, David Blagerough, British Council head of business relations, makes proposals for a survey: 'What does the weather do to people's state of mind? What would living in the other country be like? The survey will ask people to discuss propositions like: all Australian men are macho, all British men are wimps'.145 Whilst making it obvious that the survey is intended 'to plug into humour'146 about British/Australian perceptions of one another, the sub-heading nevertheless manages to appeal to the sense of climatological determinism we are apparently still mentally entrenched in: 'Is it the weather that makes all Australian men macho, and all British men wimps?'

\section{NOTES}

1 The present text grew out of a paper I was able to present at the International Medieval Congress held in July 1996 at Leeds. I am grateful to both Dr Joan-Pau Rubiès and Professor Malcolm Barber of the Department of History in the University of Reading for their constructive criticism with regards to an earlier draft of this article.

${ }^{2}$ E. Le Roy Ladurie, Times of Feast, Times of Famine: A history of climate since the year 1000, London, 1971, p.256. This warmer climate was also responsible for the plagues of locusts which hit Europe up to the midtwelfth century, even reaching northern Europe, eg. locusts were reported all the way from Germany to Spain in 873, and in the autumn of 1195 locusts got as far as Hungary and Austria (ibid). 
${ }^{3}$ A critique of Marco Polo's travels to China can be found in: F. Wood, Did Marco Polo go to China, London, 1995.

${ }^{4}$ I have used two modern editions of Odoric's accounts for this paper: 1.) M. Komroff (ed.), Contemporaries of Marco Polo, New York, repr. 1989 and 2.) H. Yule and H. Cordier, Cathay and the Way Thither, vol. II. Odoric of Pordenone, Hakluyt Society, 2nd series, no. 33. London, 1913. The latter is the more scholarly edition, using a variety of manuscripts as the basis for annotations of points in the main source, but it unfortunately omits translating some of the more "delicate" stories related by Odoric, like the episode of the overheating testicles told of the inhabitants of Hormuz.

${ }^{5}$ Other travellers, not mentioned so far, of the medieval period include Cosmas Indicopleusthes of Alexandria who travelled to the Malabar coast of India around 550 A.D. ; Theophylactus Simocatta who around 640 heard of China from envoys of an Asian Turkish kingdom to the imperial court at Constantinople: Mas'udi of Baghdad who wrote of his visits to parts of Africa, the Aral Sea and Sri Lanka in 957; and Ibn Battuta of Tangier who was the only known medieval traveller to roam as widely as Marco Polo, writing in 1368 .

${ }^{6} \mathrm{Cf}$. J. Weisheipl, Nature and Motion in the Middle Ages, Washington, DC, 1985.

${ }^{7}$ Cf. for example G. E. Hutchinson, 'Attitudes towards nature in medieval England', Isis, 65, 1974. More general: L. D. Roberts (ed.), Approaches to Nature in the Middle Ages, New York, 1972.

${ }^{8}$ CF. G. E. R. Lloyd, Demystifying Mentalities, Cambridge, 1990.

${ }^{9}$ D. Arnold, The Problem of Nature: Environment, Culture and European Expansion, Oxford, 1996, p.5.

10 Arnold, Problem of Nature, p.11.

${ }^{11}$ Arnold, Problem of Nature, p.12.

12 A. Al-Azmeh, 'Barbarians in Arab eyes', Past and Present' 134, 1992, p.3:

${ }^{13}$ Cf. R. Simek, Erde und Kosmos im Mittelalter. Das Weltbild vor

Kolumbus, Munich, 1992 for an excellent overall introduction to medieval cosmography. J. K. Wright, The Geographical Lore of the Time of the Crusades, New York, 1925, approaches the subject very schematically and provides a good collection of sources in translation. Other works in English are cited throughout in the notes below. 
${ }^{14}$ Metaphysics.

${ }^{15}$ Timaeus. The Timaeus was known in western Europe since the translation into Latin by Chalcidius in the early middle ages.

${ }^{16}$ Natural History of Pliny the Elder. Other main sources from antiquity of geographical knowledge in the medieval period are Solinus, Martianus Capella, Macrobius, Aethicus of Istria and Orosius, cf. J. K. Wright, The Geographical Lore of the Time of the Crusades, New York, 1925, p.44.

17 Cf. A. P. Newton, Travel and Travellers of the Middle Ages, London, 1930.

${ }^{18}$ On the history of maps generally cf. P. Whitfield, The Image of the World: 20 Centuries of World Maps, London, 1994; more specifically on medieval maps cf. J. G. Leithäuser, Mappae mundi, die geistige Eroberung der Welt, Berlin, 1958; M. Destombes, Mappemondes A. D. 1200-1500= Monumenta Cartographia Vetustioris Aevi Vol. I, Amsterdam, 1964; P.D. A. Harvey, Medieval Maps, London, 1991; and H. Kliege, Weltbild und Darstellungspraxis hochmittelalterlicher Weltkarten, Münster, 1991.

19 Jerome, Liber de nominibus Hebraicis, PL 23, 777.

${ }^{20}$ Angelomus, Commentarius in Genesin, PL 115, 162.

${ }^{21}$ Cf. J. B. Friedman, The Monstrous Races in Medieval Art and Thought, Cambridge, MA, 1981, p.101.

${ }^{22}$ In a five-zone set-up, running from north to south, A. P. Newton (Travel and Travellers) arrives at the following simplified zonal scheme, which provides a good illustration of the medieval concept: northern zone as uninhabitable, due to the cold, endless nights; solstitial zone as the summer zone, with a habitable, temperate climate; equinoctial zone as torrid and uninhabitable; brumal zone as winter (from brumalis) zone, temperate and habitable; and austral zone as covered with land but uninhabitable due to the cold. On the theory of seven climatic zones in Greek antiquity cf. E. Honigmann, Die sieben Klimata und die $\pi 0 \lambda \varepsilon ı \varsigma$ $\varepsilon \pi \iota \sigma \eta \mu O \imath$, [no place given], 1929.

${ }^{23}$ M. C. Seymour (ed.), Mandeville's Travels, Oxford, 1967, chapter 20, p.137, 7-9; hereafter referred to as Mandeville.

${ }^{24}$ De mundi coelestis terrae que constitutione, but possibly this work postdates Bede; cf. Newton, Travel and Travellers, pp.5-11. Augustine (De civitate dei 16.9) had already raised the issue of the antipodes; he was not necessarily against their existence per se, but seriously doubted the existence of any inhabitants; Isidore of Seville supported Augustine, as did Bede in another work, De temporum ratione, of around 725 , and in 748 
pope Zachary I strongly expressed the opinion that the existence of such a thing as the antipodes was impossible; on these and other authorities in the medieval antipodean debate cf. V. I. J. Flint, 'Monsters and the Antipodes in the early Middle Ages and Enlightenment', Viator 15, 1984, 65-80.

25 The intraversability theory has difficult theological implications: Christ saved all of humanity, not just the inhabitants of the northern hemisphere; if that is the case, then somehow missionaries must be able to reach the south (I am grateful to Prof Malcolm Barber for drawing my attention to this problem). The question of the human/ inhuman status of any inhabitants that might live in the south has been discussed by J. B. Friedman, Monstrous Races. Cf. also W. D. McCready, 'Isidore, the Antipodeans, and the shape of the earth', Isis 87(1), 1996, 108-27. With regards to strange kinds of people living in exotic places a fourteenthcentury author, John of Marignolli, makes a highly interesting, if in theological terms rather dubious, suggestion. After the murder of Abel, Cain is meant to have founded a city called Kota in Seyllan (Sri Lanka) there is a real Kotta near Colombo - where the author says he has been. The existence of the 'sons of Adam in Seyllan' are meant to prove that the Flood never reached that far, especially as Marignolli attests that 'in the eastern part of the country there are a number of roaming vagabond people whom I have seen myself, and who call themselves the sons of Cain'; these people are described in monstrous terms, with huge and terrifying faces, stinking, and like goblins. This, following Marignolli, would suggest that strange peoples are a relict from the early period of Creation, who happened to escape the Flood - a kind of medieval The Lost World. Cf. H. Yule and H. Cordier, Cathay and the Way Thither vol. III Missionary Friars - Rashiduddin - Pegolotti - Marignolli, Hakluyt Society, 2nd series, no. 37, London, 1914, pp.244-6. John of Marignolli had been papal legate to the Great Khan and afterwards bishop of Bisignano. Once back in Europe, he was asked in 1354/55 to compose a Chronicle of Bohemia for emperor Charles IV; into this he inserted his account of his Asian travels, not an unusual practice when writing a chronicle commencing with Creation.

${ }^{26}$ Cf. Wright, Geographical Lore, p.157.

${ }^{27}$ Mandeville, chapter 14, p.95.21-4

${ }^{28}$ Wright, Geographical Lore, p.162. One of the earliest proponents of an inhabitable equatorial region had been bishop Virgin of Salzburg in the eighth century, a contemporary of Boniface, famous for his missions to Germany; Boniface had the bishop accused of heresy for holding such ridiculous ideas, cf. J. Carey, 'Ireland and the Antipodes: the Heterodoxy 
of Virgin of Salzburg', Speculum 64, 1989, 1-3; also Flint, 'Monsters and the Antipodes' and note 24 above.

${ }^{29}$ Albertus Magnus, Liber cosmographicus de natura locorum, cf. Newton, Travel and Travellers, pp.5-11.

${ }^{30}$ Roger Bacon, Opus maius, cf. J. R. S. Phillips, The Medieval Expansion of Europe, Oxford, 1988, p.199.

${ }^{31}$ Cf. D. Lach, Asia in the Making of Europe, vol. I bk. 1, Chicago, 1965, p. 38, after L. Olschki, Marco Polo's Asia, Berkeley, 1960, pp.34-35.

32 The best discussion of this topos is in J. B. Friedman, Monstrous Races; also of interest are R. Wittkower, 'Marvels of the East', Journal of the Warburg Institute 5, 1942, 179-80 and more recently V. I. J. Flint, 'Monsters and the Antipodes in the Early Middle Ages and Enlightenment', Viator 15, 1984, 65-80.

33 Pliny, Natural History, II, 80.

${ }^{34}$ William of Rubruck had read the slightly earlier account of the Mongols by friar John of Plano Carpini, and 'it would seem probable from the observations made in his own report that he had also studied the major Roman writers on Asia' (D. F. Lach, Asia in the Making of Europe, vol. I, book 1, Chicago, 1965, p.33).

${ }^{35}$ P. Jackson (ed. and transl.), The Mission of Friar William of Rubruck, Hakluyt Society, 2nd series, no. 173, London, 1990, p.201. An earlier translation of the same passage (W. W. Rockhill (transl.), The Journey of William of Rubruck to the Eastern Parts of the World, 1253-1255, Hakluyt Society, 2nd series, no. 4, Nendeln, Liechtenstein, repr. 1967) reads: 'I asked [these same priests] about the monsters, or human monstrosities, of which Isidorus and Solinus speak. They told me they had never seen such, which astonished me greatly, if it be true' (ibid, p.199). The (mis)translation of this particular passage has of course very important consequences for the interpretation of William of Rubruck's views. In his translation, P. Jackson refers to P. Pelliot, Recherches sur les Chrétiens d'Asie centrale et d'extrême-orient, Paris, 1973, p.173, as having conclusively established the empirical variant of the translation - William was seen as a person who did, after all, believe what he saw and heard himself. W. Rockhill based his translation on the flawed edition of the Latin text by F. Michel and T. Wright, 'Voyage en Orient du Frère Guillaume de Rubruc', in: M. A. P. d'Avezac-Macaya (ed.), Recueil de voyages et de memoires, IV, Paris, 1839, while P. Jackson bases his translation on the more accurate and recent edition by A. Van den Wyngaert, Sinica Franciscana, I. Itinera et relationes fratrum minorum 
saeculi XIII et XIV, Karachi - Florence, 1929. Interestingly enough in the earlier (mis)translation, W. Rockhill has a sentence a little later in the same controversial passage which quite clearly shows the scepticism of William of Rubruck: 'They also told me as a fact (which I do not, however, believe), that there is a province beyond Cathay, and at whatever age a man enters it, that age he keeps which he had on entering' (William of Rubruck, ed. Rockhill, p. 200). On European reception of narratives regarding the Mongols cf. J. Fried, 'Auf der Suche nach der Wirklichkeit: Die Mongolen und die europäische Erfahrungswissenschaft im 13. Jahrhundert', Historische Zeitschrift, 243, 1986, 287-332, and J. Fried, 'Anschauung und Begriff: Die Bewältigung fremder Wirklichkeit durch den Vergleich in Reiseberichten des späten Mittelalters, Historische Zeitschrift, 253, 1991, 281-312.

36 Yule, Cathay vol. III, p.256. Marignolli does however continue by narrating stories relating to the existence of giants and wild men (p. 259), though again he disbelieves tales of humanoid monsters, saying 'they may seem to have some of the properties of men, but are merely of the character of apes; (indeed if we had never seen apes before we should be apt to look upon them as men)' (p.260).

37 C. Markham (ed. and transl.), Libro del Conoscimiento, Hakluyt Society, 2nd series, no. 29, London, 1912.

${ }^{38}$ Arnold, Problem of Nature, p.143. Jan Myrdal, Kunst und Imperialismus am Beispiel Angkor, Munich, 1973 (Swedish edition 1968), has pointed out that the image of tropicality as 'other' is not restricted to northern Europeans: from a Chinese perspective the peoples living to the south of the empire are physically deformed by the heat in that region, cf. Myrdal, pp.16 ff. 'Das nordische Huhn und Angkor' on the theories of heat and culture.

${ }^{39}$ Cf. A. Katzenellenbogen, 'The central tympanum at Vezelay: its encyclopedic meaning and its relation to the first Crusade', Art Bulletin $26,1946,141-51$, for an interpretation of the symbolism of some of the monstrous races and their link with Isaiah's prophecies, especially on the mission of the apostles with its implications for medieval missionary activity.

40 On medieval interpretations of Alexander the Great and the stories associated with him cf. G. Cary, The Medieval Alexander, Cambridge, 1956. A translation of the relevant passages of Pseudo-Callisthenes, Gesta Alexandri, appears in: G. Boas, Essays on Primitivism and Related Ideas in the Middle Ages, Baltimore, 1948, pp.140-46. 
${ }^{41}$ According to Pliny the Elder, Natural History, cf. J. B. Friedman, Monstrous Races.

42 Hippocrates, Airs, Waters, Places, xii, says that everything in Asia Minor differs from Europe, ie. Greece, even the vegetation grows better and bigger. 'The cause of this is the temperate climate, because it lies towards the east midway between the risings of the sun, and farther away than is Europe from the cold' (ibid). This treatise is not to be underestimated, it was to be of lasting influence on ideas about the environment, medicine and ethnology for the next 2300 years. The (mis)readings and interpretations of this text are unfortunately also responsible for the fallacy that if 'environmental influences on the physical and mental qualities of individuals can be shown, they can by extension be applied to whole peoples' (G. Glacken, Traces on the Rhodian Shore: Nature and Culture in Western Thought from Ancient Times to the End of the Eighteenth Century, Berkeley/ Los Angeles, 1967, p.88), thereby opening the intellectual door to racism.

${ }^{43}$ Herodotus, Histories IX:122 on environmental correlations with culture, especially with regards to the Persians, of whom he says 'soft countries breed soft $[\mu \alpha \lambda \alpha \kappa o \varsigma]$ men'.

${ }^{44}$ Plato, Laws IV 704D-705D on the relationship between the virtue of a people and their geographical location.

45 Aristotle, Politics VII, 7, 1327B, making the statement on the golden mean, 'one of the most influential statements ever made regarding the relation of climate to peoples' (Glacken, Rhodian Shore, p. 93). Cf. also Aristotle's Problemata $1,909^{\mathrm{a}} 13-17 ; 8,909^{\mathrm{b}} 8-25 ; 15,910^{\mathrm{a}} 26-35$.

${ }^{46}$ Such as Cicero, Ptolemy, and Caesar.

47 John Scotus Erigena, De divisione naturae II, 7, PL 122, 533B: '....sed ex vitio, et diversitate locorum et temporum terrarum, aquarum, aërum, escarum, ceterarumque similium, in quibus nascuntur et nutriuntur ...'.

${ }^{48}$ Isidore, Etymologiarum libri, 9.2.105, ed. W. M. Lindsay, Oxford, 1957.

${ }^{49} \mathrm{Eg}$. in the texts of Gervase of Tilbury, Alexander Neckham, Thomas of Cantimpré, Albertus Magnus, Thomas Aquinas, Bartholomaeus Anglicus, Robert Grosseteste and Roger Bacon; the didactic poem Canticum de medicina by Avicenna (980-1037) was also influential. Cf. Glacken, Rhodian Shore, pp.263-4.

50 Otia Imperialia of Gervase of Tilbury, quoted in: J. Critchley, Marco Polo's Book, Aldershot, 1992, p.47. 
51 Jacques de Vitry, Historia Ierosolymitana seu Orientalis, in: Critchley, Marco Polo's Book, p.47.

52 P. Tilmann, An Appraisal of the Geographical Works of Albertus Magnus, Ann Arbor, 1971, 1.11, p.77; 2.3, p.104, quoted by Friedman, Monstrous Races, p.53.

${ }^{53}$ Cf. A. Al-Azmeh, 'Barbarians in Arab eyes', Past and Present 134, 1992, pp.8-11; on Arabic views on cosmography cf. also B. Lewis, 'Muslim perceptions of the world', Comparative Civilizations Review 13(1), 1986, 3-16.

${ }^{54}$ Al-Azmeh, 'Barbarians', p.8.

55 Ibid, p. 6.

56 C. Fahlin (ed.), Chronique des Ducs de Normandie, by Benô̂t, Lund, 1951, 11.131-143.

57 Cf. Friedman, Monstrous Races, p.54.

58 Pietro de Crescenzi (1230-1320/1), known as Petrus de Crescentiis and as Pierre de Crescens, from Bologna, wrote a very successful treatise on husbandry, which was translated from Latin into French in 1373 at the behest of Charles V of France. The discussion of the different airs (hot, cold, humid, dry) of a place and their suitability and drawbacks for habitation are right at the beginning of the text, with Pietro stating he is following Avicenna.

${ }^{59}$ Pierre de Crescens, Les profits champêtres, transl. J. Roubinet, Paris, 1965 , p.19 (a facsimile edition of the fifteenth-century MS, Paris, Bibliothèque de l'Arsenal Cod. 5064).

60 Ibid, p. 21.

${ }^{61}$ Mandeville, chapter 18, p.119, 12-14.

${ }^{62} \mathrm{I}$ am indebted to Professor Malcolm Barber for drawing my attention to this point.

63 'In hoc autem quod abstinent vino propter calidus regiones in quibus habitant, ne nimio calore periclitentur, physicam in hoc magistri sui doctrinam sequuntur, etc', Gerald of Wales, De principis instructione liber (=Giraldi Cambrensis Opera, vol.8), ed. G. F. Warner, Rolls Series, vol. 21,1891, p.68. Gerald at an earlier stage relates the derogatory Christian myth of how Mohammed died: he was drunk through wine (vinolentus) one night, wandered outside, and got killed by pigs. Hence the abstinence from wine in particular. 
64 'Proinde, quoniam libidinosos novit Orientales, calore regionis urgente et ad hoc impellente, cuilibet tot uxores et concubinas quot de facultatibus suis sustenare valeret pro legis articulo habere concessit.' De principis instructione liber, p.70.

65 'Sicut et eadem arte hostis antiqui haeretici nostri temporis, Patari scilicet, ad decipiendum nunc utuntur; in frigidis enim his zonis, ubi constringit algor et avaros reddit, suadent hominibus avaritiam, suggerentes et quasi pro lege statuentes decimas non esse sacerdotibus dandas nec oblationes ecclesiis faciendas'. De principis instructione liber, p. 70 .

66 Albertus Magnus, De natura locorum, Tr. II, chapter 3. Human beings are not just at the mercy of their environment, though, as Albertus Magnus, again following ancient authors (Theophrastus via Pliny), asserts that people can change a hostile environment in their favour, especially by cutting trees (Cf. Glacken, Rhodian Shore, p.270).

${ }^{67}$ R. Latham (transl.), The Travels of Marco Polo, Harmondsworth, 1958, p. 240 .

\section{${ }^{68}$ Marco Polo, trans. Latham, p.245}

69 In Marco Polo, Odoric of Pordenone and other travellers' texts nudity or nakedness is often mentioned as an attribute of the people to be found in exotic locations. Phrases like 'complete nudity' are often subsequently qualified by the addition 'except for a loincloth', or such like. Nudity in this case is not what the late twentieth century understands by the term, but nudity and nakedness exist in varying degrees, so that a person can be 'completely naked' and yet still wear some item of clothing. The semiotic hierarchy within different concepts of nudity/nakedness has been discussed by R. Jütter, 'Der anstößige Körper. Anmerkungen zu einer Semiotik der Nacktheit' in: K. Schreiner and N. Schnitzler (eds.), Gepeinigt, begehrt, vergessen. Symbolik und Sozialbezug des Körpers im späten Mittelalter und in der frühen Neuzeit, Munich, 1992, pp.109-29. Vestiges of a differentiated notion of nudity/nakedness still exist in modern times. In the English language, for example, nudity and nakedness as qualifiers can both be applied to a person (they are nude/they are naked) whereas only nakedness can qualify an object or an abstraction (the naked, but not the nude, truth).

${ }^{70}$ Marco Polo, trans. Latham, p.262. Odoric of Pordenone, visiting India after Marco Polo, describes the inhabitants of Polumbum (Colombo) in Sri Lanka in similar words: 'here all the people go naked, only they wear a 
cloth just enough to cover their nakedness, which they tie behind' (Yule, Cathay, vol. II, p.137).

${ }^{71}$ Ibid. p.261. Mandeville tells a similar tale about the sea off Libya, where there are no fish because the sun is so hot that the water is always boiling because of the heat (Mandeville, chapter 16).

${ }^{72}$ Marco Polo, trans. Latham, p.30.

${ }^{73}$ Marco Polo, trans. Latham, p.262.

74 This is a quite arbitrary topos, but one that apparently fits in well with the European image of the 'other'. The great Arabic traveller Ibn Battuta (see note 5 above) mentions that the Tuareg (Ibn Battuta calls them Targui) of the Sahara, and many other desert-dwellers, cover themselves completely as a protection against the sun and heat; cf. H. A. R. Gibb (trans. and ed.), Ibn Battuta, Travels in Asia and Africa, 1325-1354, London, 1929, p.337; and L. C. Briggs, Tribes of the Sahara, Cambridge, MA, 1967, p.155.

${ }^{75} \mathrm{M}$. Letts (ed. and transl.), The Pilgrimage of Arnold von Harff, Hakluyt Society, 2nd series, no. 94, London, 1946, p.165.

76 Arnold von Harff, p. 167. Arnold never actually travelled as far as India. It appears he made the acquaintance of someone on an embassy from India to Egypt while Arnold was staying in Cairo which so impressed him that he had to add stories about India into his Pilgrimage without ever having been there.

77 Die Fahrt des Afanassij Nikitin über drei Meere 1466-1472 von ihm selbst niedergeschrieben, transl. by I. Mirus, Munich, 1966, p.16.

${ }^{78}$ Afanassij Nikitin, p. 17. In another town of India, too, the attendants of the 'sultan' wear only a cloth around their loins but are otherwise completely naked (ibid, p.33).

79 Yule, Cathay, vol. II, p.147.

${ }^{80}$ In that lond is fulle gret hete. And the custom there is such that men and wommen gon alle naked, and thei scornen whan thei seen ony strange folk goynge clothed. And thei seyn that God made Adam and Eue alle naked...', Mandeville, chapter 20, p.131, 5-14.

81 '... and that no man scholde schame him to schewen him such as God made him, for nothing is foul that is of kyndely nature. And thei seyn that thei that ben clothed ben folk of another world or thei ben folk that trowen not in God. And thei seyn that thei beleeuen in God that formed the world and that made Adam and Eue and formed alle other thinges', Mandeville, chapter 20, p.131, 5-14. 
${ }^{82}$ Arnold von Harff, p.167.

83 Cf. Al-Azmeh, 'Barbarians', p.13.

${ }^{84}$ Reminiscent of the battle practices of Celtic and Germanic tribes as described by Roman authors, eg. Tacitus, another people seen as 'noble savages' by their 'civilised' neighbours.

85 Yule, Cathay, vol. II, p.170.

${ }^{86}$ Arnold von Harff, p.168.

87 On the topoi of 'isles of the blessed', 'fortunate isles' and regarding notions of a physical location of the earthly paradise cf. G. Boas, Essays on Primitivism and Related Ideas in the Middle Ages, Baltimore, 1948.

88 Cf. R. Günther and R. Müller, Sozialutopien der Antike, Leipzig, 1987, pp. 84-86.

${ }^{89}$ Cf. F. Graus, 'Social utopias in the middle ages', Past and Present, 38, 1967 , p.7.

${ }^{90}$ From the anonymous treatise Description of the whole world and its races, a Latin version of a Greek original text (compiled late in the 4th century); the Latin text was revised at a much later stage and worked over by a Christian writer, in: Newton, Travel and Travellers, p. 27.

${ }^{91}$ Mandeville, chapter 18, p.120, 16-24.

${ }^{92}$ M. A. Signer (ed.), The Itinerary of Benjamin of Tudela: Travels in the Middle Ages, Malibu, CA, 1983, pp.120-1.

93 See note 36 above.

${ }^{94}$ Marco Polo, trans. Latham, p. 245.

95 On the topic of concepts of India, rather than just topographical descriptions, also cf. D. F. Lach, Asia in the Making of Europe, vol. II, book 2, Chicago, 1977, pp.85-99.

${ }^{96}$ Clavijo, Embassy to Tamerlane 1403-1406, transl. G. Le Strange, London, 1928, p.159.

${ }^{97}$ In: Newton,Travel and Travellers, p.169

${ }^{98}$ Mandeville, chapter 16, p.106, 15-17.

${ }^{99}$ Mandeville, chapter 17, p.114, 27-33.

100 P. Tilman, An Appraisal of the Geographical Works of Albertus Magnus, Ann Arbor, 1971, 2.3, p.101, cited in Friedman, Monstrous Races, p.54. 
${ }^{101}$ Zenj or Zanj/Zang were Arab names for all of the east African coast.

102 On European representation of black people in general cf. L. Bugner (gen. ed.), The Image of the Black in Western Art, 3 vols., New York, 1976-1989: vol. II, From the Early Christian Era to the Age of Discovery, in 2 parts.

${ }^{103}$ Marco Polo, trans. Latham, p. 276.

104 Marco Polo assumed Zenj [Zanzibar] was an island.

105 Marco Polo, trans. Latham, p.276.

${ }^{106}$ De civitate dei 16.9, cf. Flint, 'Monsters and the Antipodes', p.74.

107 M. T. Hodgen, Early Anthropology in the Sixteenth and Seventeenth Centuries, 2nd edition, Philadelphia, 1971, pp.213-4, cited in Flint, 'Monsters and the Antipodes', p.79 n. 39.

${ }^{108}$ In: L. Thorndike, A History of Magic and Experimental Science, Vol. I, 2nd printing with corrections, New York, 1929, p. 658. Costa ben Lucca wrote a medico-philosophical treatise, On the Difference between Soul and Spirit, which was translated into Latin in the twelfth century by John of Spain, subsequently the text was found in many manuscripts, often bound together with the works of Aristotle (cf. Thorndike, p. 657). Costa ben Lucca also attempted a materialist explanation of how the thought process functions: in the brain there is a valve between the posterior and anterior ventricles, and the spiritus passes through this valve from the anterior to the posterior ventricle when a person is engaged in thought, therefore the clearer the spiritus is, the faster it can move across, therefore the more quickly that person can think. In this context the environmentalist view of hot weather making people sluggish parallels Costa ben Lucca's anatomical rationale.

109 Cf. Al-Azmeh, 'Barbarians', p. 9 and n. 23.

110 A recent survey of 'racial science' and the theories about race that still exist today can be found in M. Kohn, The Race Gallery: The Return of Racial Science, London, 1995. As science, since the late eighteenth century, detaches itself from the Bible as the notion of truth, so the idea of all humans stemming from Adam and Eve, the idea of monogeny, begins to lose ground. Monogeny, as was the predominant medieval view of humanity, 'was somewhat harder to reconcile with racial purity' (ibid, p.29), but 'scientific progress' and the vast spans of geological time established in fossil finds pathed the way for a view of humanity as being polygenous, thereby allowing the view that some gens is superior to another after a rational, scientific fashion. 
111 Mandeville, chapter 7, p.33, 8-9.

112 The Travels of Sir John Mandeville were originally written in French, becoming one of the most widely read travelogues so that by the end of the medieval period, around 1500 , some version of the text was available in translation in most European languages. The passage cited above is based on the version using an early Anglo-Norman Mandeville-text, in the fourteenth-century British Library MS Harley 4383, in C. W. R. D. Moseley (ed. and transl.), The Travels of Sir John Mandeville, Harmondsworth, 1983.

${ }^{113}$ The Travels of Sir John Mandeville, ed. Moseley, p.64.

114 Philippe de Mezières, 'Songe d'un vieil Pélerin', Paris, Bibliothèque de l'Arsenal MS 2682, f. 52, cited in : O. G. S. Crawford (ed.), Ethiopian Itineraries circa 1400-1524, Hakluyt Society, 2nd series, no. 109, Cambridge, 1958, p.4.

${ }^{115}$ Cf. Al-Azmeh,'Barbarians', p.11. Bilal, famous for his stentorian voice, was an Ethiopian and one of the first followers of Mohammed. As 'people of the book', having a religion based on a text, Christians (irrespective of skin colour) were automatically accorded higher status than 'idolaters', people without such religious texts, in Islamic thought.

116 Cf. C. Trasseli, 'Un italiano in Etiopia nel XV secolo: Pietro Rombulo da Messina', Rassegna di Studi Etiopici, 1, 1941, 173-202.

${ }^{117}$ Pietro Ranzano, born 1428 in Palermo, compiled a vast Annales ( MS in Biblioteca Communale, Palermo), consisting of a rambling world history, including an account of his meeting with Rombulo and the eyewitness descriptions of the country of Ethiopia that Rombulo could provide. Unfortunately Ranzano also uses other accounts of Africa, from the mythical tradition, to augment the factual material he obtained from Rombulo. Cf. Crawford, Ethiopian Itineraries, pp.5-8.

${ }^{118}$ Francesco Suriano, so-called 'Iter S', in: Crawford, Ethiopian Itineraries, p.45.

119 Saewulf, 'A Reliable Account of the Situation of Jerusalem', in: J. Wilkinson, J. Hill and W. F. Ryan, Jerusalem Pilgrimage 1099-1185, Hakluyt Society, 2nd series, no. 167, London, 1988, p.101.

${ }^{120}$ Mandeville, chapter 7, p.33, 1.

${ }^{121}$ Arnold von Harff, p.114.

122 Ibid, p.138.

${ }^{123}$ Ibid. 


\section{Ibid, p.184.}

125 John of Montecorvino, born 1247, died around 1328, was the founder of the catholic mission to India, living there in the 1290s. A letter of his was cited and copied by another friar, the Dominican Menentillus of Spoleto writing to yet another fellow friar; cf. H. Yule and $\mathrm{H}$. Cordier, Cathay and the Way Thither, vol. III: Missionary Friars - Rashiduddin Pegolotti - Marignolli, Hakluyt Society, 2nd series, no. 37, London, 1914.

\section{Yule, Cathay, vol. III, pp. 63-4.}

${ }^{127}$ Benjamin of Tudela, ed. Signer. Benjamin of Tudela's comment on the literacy of the Jews of Khulam should be understood in the same sense as Islamic comments on Christians as 'people of the book' - skin colour is deemed of less importance than adherence to a religion based on the text (see note 115).

${ }^{128}$ Marco Polo, trans. Latham, p.47.

${ }^{129}$ Marco Polo, trans. Latham, p.39.

${ }^{130}$ Dindimi de Vita Bragmanorum, a text incorporated into the Romance of Alexander by the Pseudo-Callisthenes, in: L. Olschki, Marco Polo's Asia, transl. J. A. Scott, Berkeley and Los Angeles, 1960.

${ }^{131}$ Cf. Olschki, Marco Polo's Asia, p.426 n.59.

${ }^{132}$ Mandeville, chapter 5, p.20, 17-22.

${ }^{133}$ Benjamin of Tudela, ed. Signer, p.98. As an interesting aside, maristan means hospital (Persian ending -stan), and Arabic maridun signifies ill/ sick, derived from which modern German still uses the expression marode to denote a sickly person or dilapidated thing.

134 Ibid.

${ }^{135}$ Marco Polo, trans. Latham, p.35.

${ }^{136}$ Marco Polo, trans. Latham, p.36.

${ }^{137}$ Marco Polo, trans. Latham, p.286. Modern houses in southern Iran and in Dubai are still built according to this design.

138 Yule, Cathay, vol. II, p.112. Yule omits in his edition of Odoric's text to translate what follows - see note 4 above.

${ }^{139}$ Komroff, Contemporaries of Marco Polo, p.217.

${ }^{140}$ Mandeville, chapter 18, p.120,11ff: 'But there is so grete hete in tho marches, and namely in that ile, that for the grete distress of the hete 
mennes ballokes hangen doun to here knees for the grete dissolucoun of the body. And men of that contree that knowen the manere lat bynde hem $\mathrm{vp}$, or elles myghte thei not lyue, and anoynt hem with oynementes made therfore to holde hem vp'.

${ }^{141}$ Afanassij Nikitin, p.16. The rather repetitive list of hot places is a wonderful example of a travellers completely subjective views along the lines of 'here you eat well, here you don't': 'In Gundustan aber ist keine große Hitze; große Hitze ist zu Gurmys und zu Katobagrjaim, wo es Perlen gibt, auch zu Schida, auch zu Baka [Baku], auch zu Misjura, auch zu Ostan, auch zu Lar; und im Lande Chorossan [northern Iran] ist es heiß, aber nicht so sehr, und in Tschegotan ist es sehr heiß; auch zu Schiras, auch zu Jesda [Jesd in Iran]; zu Kaschin [Iran] ist es heiß, aber es weht ein Wind, aber zu Giljan ist es sehr stickig und große Schwüle, auch zu Schamacha [on Caspian Sea] ist es schwül; auch zu Wawilon [Babylon] ist es heiß, auch zu Chumit und zu Schama ist es heiß, aber zu Ljapa ist es nicht so heiß' (ibid, p.33).

${ }^{142}$ Hayden White, 'The Forms of Wilderness' in E. Dudley and M. Novak (eds.), The Wild Man Within: An Image in Western Thought from the Renaissance to Romanticism, Pittsburgh, 1972, pp.6-7, cited by Friedman, Monstrous Races, p.148.

143 Now in the Prado, Madrid.

${ }^{144} \mathrm{~J}$. Mortimer, 'Sweaty socks in the sun-dried shires', The Guardian, 6 July 1996.

145 D. O'Reilly, 'Tiny kangaroos are sport...', The Guardian, 5 December 1996.

146 Ibid. 